\title{
Efficacy of Three Bio-pesticides and Oxamyl Against Citrus Nematode (Tylenchulus semipenetrans) and on Productivity of Washington Navel Orange Trees
}

\author{
M. M. El-Tanany *, M. S. El-Shahaat ${ }^{* *}$ and M. S. Khalil ${ }^{\text {** }}$ \\ ${ }^{*}$ Citriculture Division, Horticulture Research Institute and ${ }^{* *}$ Central Agricultural \\ Pesticides Laboratory, Agricultural Research Centre, El-Sabhya Station, Alexandria, \\ Egypt.
}

\begin{abstract}
STUDY was conducted during two periods (March and September), for two successive $A$ growing seasons (2016 and 2017) to determine the impacts of three bio-pesticides products namely, abamectin $\left(\right.$ Tervigo $\left.^{\circledR}\right)$, azadirachtin $\left(\right.$ Achook $\left.^{\circledR}\right)$ and a mixture of Trichoderma album + Bacillus megaterium (Bio Zeid ${ }^{\circledR}+$ Bio Arc $^{\circledR}$ ), as well as oxamyl $\left(\right.$ Vydate $\left.^{\circledR}\right)$, on the number of citrus nematode populations (Tylenchulus semipenetrans), on 10-year-old Washington navel orange trees (Citrus sinensis, Osbeck) budded on sour orange rootstock grown in sandy soil. This work was carried out in private farm located at Hamour village, Boustan area, Behera governorate. The obtained results proved that all treatments reduced nematode populations during both seasons from 63.04 to $79.66 \%$ and from 69.53 to $89.87 \%$, respectively. Meanwhile, the fruit yield during both seasons was increased significantly with all applied treatments, especially oxamyl treatment. The most of physical fruit properties were improved. Chemical fruit properties were markedly improved, especially with abamectin treatment which increased vitamin C. Moreover, oxamyl and azadirachtin significantly raised total solid soluble content in the fruit juice.

On the other hand, the leaf area was augmented through both seasons in all treatments. The leaf minerals composition also was increased with all applied treatments, except for calcium which significantly decreased with the mixture of $T$. album + B. megaterium during both seasons of study.
\end{abstract}

Keywords: Tylenchulus semipenetrans, Washington Navel orange, Fruit yield, fruit properties, Mineral composition and Bio-pesticides.

\section{Introduction}

Citrus especially oranges, play an important role in the agricultural production and economy. Orange crop in Egypt is considered as the most fruit production destined for exportation. Unfortunately, the citrus orchards are severally infested by numerous species of parasitic nematodes associated with the citrus rhizosphere system in all different soil texture types.

The most widespread genera of parasitic nematodes in citrus orchard is Tylenchulus semipenetrans. This serious pest cause significant economic losses. Most studies estimated yield losses of Navel orange tress according to $T$. semipenetrans to be in the range of $10-30 \%$ depending on the level of infestation. Moreover, T. semipenetrans nematode is a dominant pathogenic species and the most important in most citrus regions in the Egyptian agricultural soils. It is well known that young trees appeared to poorly grow when planted into nematode - infested soil (Duncan and Cohn, 1990 and Verrdejo-Lucas and McKenry, 2004). In Egypt, the control of plant parasitic nematodes is recommended when nematode count reaches to 7000-9000 juveniles / $\mathrm{kg}$ soil sample.

The number of females infesting roots is the best indicator for seasonal activity of Tylenchulus semipenetrans (Sorribas et al., 2000) and also for evaluating the efficacy of nematicides (Hamid et al., 1988). The present study was conducted in order to evaluate the influence of three biopesticides namely, abamectin, azadirachtin and a mixture of two antagonistic microbes 
(Trichoderma album + Bacillus megaterium), as well as oxamyl as standard nematicide against T. semipenetrans nematodes in relation to study their effects on the productivity of Washington navel orange trees.

\section{Materials and Methods}

The present investigation was conducted in a private orchard located at Hamour village, Boustan area, Behera governorate, Egypt during the 2016 and 2017 seasons on ten years old Washington Navel orange trees (Citrus sinensis, Osbeck) budded on sour orange rootstock grown in sandy soil. The main goal of this study was to evaluate the impact of some chemical and natural nematicides on yield, fruit quality, leaf area, and leaf mineral composition.

Mature twenty trees of Washington navel orange trees were used in this study, the selected trees were nearly uniform in vigor and size and spaced at 4 X $5 \mathrm{~m}$ apart (200 trees / Fed.), and received the same cultural practices usually adopted for this area according to the recommendation of Horticulture Research Institute, Ministry of Agriculture, Egypt . Surface drip irrigation system was used in the orchard. Trees received $6500 \mathrm{~m}^{3}$ of water per feddan per year distributed through the whole year. The fertigation program included $51 \mathrm{Kg}$ nitrogen as ammonium sulphate and $67 \mathrm{~kg}$ ammonium nitrate, $62.5 \mathrm{~kg}$ potassium as potassium sulphate, $50 \mathrm{~kg}$ magnesium as magnesium sulphate and $32 \mathrm{~kg}$ orthophosphoric acid per feddan per year distributed from February till October.

Besides, the trees were also sprayed with crystalon (19: 19: 19 N P K) only once, at bud sprouting in March at the rate of $4 \mathrm{Kg} / 600$ Liters water. In addition, trees were sprayed with (250gm chelated iron $12 \%, 250 \mathrm{gm}$ chelated manganese $14 \%$, 200gm chelated zinc $13 \%$ and $750 \mathrm{~cm}^{3}$ amino acid solution / 600 Liters of water), two times, at bud sprouting in March and during fruit growth, in August.

\section{The applied treatments are presented as follows:}

1. Control (untreated trees).

2. Vydate ${ }^{\circledR} 24 \%$ SL 'Oxamyl', used at the rate of 3 liters / Feddan $\left(15 \mathrm{~cm}^{3} /\right.$ tree $)$.

3. Tervigo ${ }^{\circledR} 2 \% \mathrm{SC}$ "Abamectin", used at the rate of 2.5 liters / feddan $\left(12.5 \mathrm{~cm}^{3}\right.$ / tree $)$.

4. Achook $^{\circledR} 0.15 \%$ EC " Azadirachtin', an insecticide used at the rate of $750 \mathrm{~cm}^{3}$ / feddan $\left(3.75 \mathrm{~cm}^{3} /\right.$ tree $)$.
5. A mixture of Bio Zeid ${ }^{\circledR} 2.5 \%$ WP "contains $1 \times 10^{7}$ cell / g of fungus, Trichoderma album and Bio $\operatorname{Arc}^{\circledR} 6 \%$ WP 'contains $25 \times 10^{6}$ cell / $\mathrm{g}$ of bacterium, Bacillus megaterium which used at the rate of $10 \mathrm{Kg} /$ Feddan $(50 \mathrm{~g} /$ tree).

The applied compounds were obtained from local markets at El-Nubarya zone. The treatments were applied under dripper at depth of $5-10$ $\mathrm{cm}$ from soil surface. The applied treatments were carried out twice per season at March and September. Each treatment was replicated 4 times. The populations of citrus nematode (Tylenchulus semipenetrans), were recorded throughout soil samples of each replicate which were taken directly before application and after the treatments by a month for both seasons 2016 and 2017 .

The soil samples were collected according to Barker (1985). Three sub-samples were collected from 10 to $30 \mathrm{~cm}$ depth of each replicate to form a composite sample of approximately $2 \mathrm{~kg}$, which was then thoroughly mixed. The second stage juveniles (J2) of Tylenchulus semipenetrans were extracted from a $200 \mathrm{~g}$ sub-sample soil of each replicate, using the sieving and Baermann plates' technique (Ayoub, 1980), and counted under a stereomicroscope. The reduction in the nematode population density expressed as a percentage was calculated at the termination of the experiment according to Henderson and Tilton's equation (1955) as follow:

$$
\text { Reduction }(\%)=\left\{1-\left(\frac{\mathrm{a}}{\mathrm{b}} \mathrm{X} \frac{\mathrm{c}}{\mathrm{d}}\right)\right\} \times 100
$$

Where:

$\mathrm{a}=$ Population density in treatment after application

$\mathrm{b}=$ Population density in treatment before application

$\mathrm{c}=$ Population density in check untreated (control) before application

$\mathrm{d}=$ Population density in check untreated after application

leaf analysis

Leaf samples of 20 - 30 full expanded mature leaves was taken from non - fruiting shoots of the previous spring growth flushes. Leaves were collected from all over the circumference of each tree. Leaf samples were taken at random on October, 22 of each season. Leaf samples were washed with tap water, rinsed three times in distilled water, oven dried at $65-70 \mathrm{C}^{\circ}$ to a constant weight and grounded to 20 mesh size. Leaf samples were 
used for total nitrogen, phosphorus, potassium, calcium and magnesium determination. A sample of $0.3 \mathrm{~g}$ of the ground dry material was digested with sulphuric acid and hydrogen peroxide according to Evenhunis and DeWaard (1980). In digested solution of each sample, total nitrogen, phosphorus were colorimetrically determined according to Evenhunis (1976) and Murphy and Riky (1962), respectively. Potassium was measured against a standard using carlzeisis Jena flam photometer. Calcium and magnesium were determined by Vesenate method using eirochrom black $\mathrm{T}$ and ammonium purpurate indicator for calcium plus magnesium and calcium, respectively (Cheng and bray, 1951).

\section{Leaf area}

The Leaf area of each experimental tree was measured using a planimeter by tracing the outline of eight (8) representative leaves.

\section{Fruit number and Yield}

During October of 2016 and 2017 seasons, fruit number of each tree for both experimental seasons was recorded on October, 22. Average fruit weight of 10 mature fruits randomly selected was estimated for each tree. At harvest fruit yield of each experimental tree was then calculated as $\mathrm{Kg}$ per tree and ton per feddan.

\section{Fruit quality:}

At harvest time (on December, 12) of both seasons, average fruit length, diameter, fruit and pulp weights, rind weight, its thickness and juice volume of eight fruits, randomly taken from each tree, were determined. Total soluble solids content (TSS) in fruit juice was recorded by hand refractometer. Acidity as citric acid percent was determined by titration using $0.1 \mathrm{~N}$ sodium hydroxide. Vitamin $\mathrm{C}$ content in the juice was estimated by titration with 2,6 dichlorophenol endophenol dye (A.O.A.C., 1995).

All previous treatments were arranged in a Randomized Complete Blocks Design (RCBD) with four replicates for each treatment. The obtained data were statistically analyzed using analysis of variance technique. Means were compared using LSD method at 0.05 level of probability using Costat program (version 6.303, 2005). A combined analysis for both experimental seasons of fruit yield (as $\mathrm{kg} / \mathrm{tree}$ ) was carried out according to Gomez and Gomez (1984). Simple correlations were done according to Steel and Torrie (1980) between the number of nematode populations and both total fruit number/tree and fruit yield as well as an average of leaf area after the application of nematicides.

\section{$\underline{\text { Results and Discussion }}$}

The impact of some bio-pesticide products on the soil population of citrus nematode, Tylenchulus semipenetrans

Data presented in Table 1 illustrated the effect of three bio-pesticides products namely, abamectin (Tervigo ${ }^{\circledR}$ ), azadirachtin $\left(\right.$ Achook $^{\circledR}$ ) and a mixture of Trichoderma album + Bacillus megaterium (Bio Zeid ${ }^{\circledR}+$ Bio Arc $^{\circledR}$ ), as well as oxamyl $\left(\right.$ Vydate $\left.^{\circledR}\right)$ on the presence of citrus nematode populations in the soil during two periods (March and September), for two successive seasons 2016 and 2017. The numbers of the populations were recorded before and after application by a month. Results in the first period (March, 2016) abamectin and oxamyl were the superior treatments which reduced the population by 79.66 and $79.61 \%$, respectively, followed by the mixture of (T. album + B. megaterium) and azadirachtin by 78.79 and $74.94 \%$, respectively. The same trend was observed in the second period (September, 2016) where abamectin proved its superiority and reduces the soil population by $78.12 \%$, followed by oxamyl, the mixture of ( $T$. album + B. megaterium) and azadirachtin with $72.78,66.20$ and $63.04 \%$ reduction, consecutively.

The obtained results of the present work was confirmed by Davis and Wilhite (1985) who found that oxamyl and fenamiphos were effective for managing citrus nematode (Tylenchulus semipenetrans) in the soil of grapefruit for two successive seasons. Meanwhile, oxamyl failed to improve the yield of grapefruit during both seasons.

Recently, abamectin which is a new registered nematicide in Egypt had recorded a highly nematicidal performance against Tylenchulus semipenetrans. Certain reports showed that abamectin was able to reduce certain genera of plant parasitic nematodes such as Meloidogyne, Ditylenchus, Radopholus, Hoplolaimus and Tylenchorhynchus on several crops (Blackburn et al., 1996, Jansson \& Rabatin, 1998, Becker, 1999, Khalil et al., 2012, El-Nagdi et al., 2015 and Saad et al., 2017). Also, it was found that abamectin reduced the soil population of $T$. semipenetrans in mandarins up to $86 \%$ during the first season, while in the second season minimized the soil population up to $93 \%$ (El-Nagdi et al., 2010). The effect of abamectin against the citrus 
nematodes (T. semipenetrans) in our study may be attributed to the strong adsorption of abamectin on soil particles which help abamectin to stay in direct contact for more time with the nematode population (Huang et al., 2014 and Lopez-Perez et al., 2011). Furthermore, abamectin causes immobility in second stage juveniles $\left(\mathrm{J}_{2}\right)$ of root knot nematode and this may correlate with a reduction in oxygen uptake (Nordmeyer and Dickson, 1989).

On the other hand, in the second season (2017), the intervals during the two periods (March \& September), showed that all applied treatments minimized the soil population significantly. In the first period (March, 2017), the highest reductions were observed with oxamyl, azadirachtin and abamectin with 89.87 , 86.26 and $84.96 \%$, respectively. The mixture of (T. album + B. megaterium) was relatively the least effective treatment with $75.07 \%$ reduction. In the second period (September, 2017), abamectin $(87.06 \%)$ and oxamyl $(82.44 \%)$ had possessed the best effectiveness in controlling juveniles of Tylenchulus semipenetrans in the soil. However, azadirachtin and the mixture of (T. album $+B$. megaterium), were the least treatments which came in the next category with relative reductions by 72.74 and $69.53 \%$, respectively.

According to this study the activity of azadirachtin as a nematicide was moderate. The water extract of neem leaves recorded the superior mortality in the soil final population of $T$. semipenetrans, significantly than Datura alba and Calotropis procera on Citrus jambhiri (Ahmed et al., 2004). The neem seed extract contains azadirachtin which is complex tetranortriterpenoid. Azadirachtin which is the main component of neem is responsible for both antifeedant and toxic effects in plant nematode as in insects (Mordue \& Nisbet, 2000). Also, the active constituents of neem which absorbed through plant root can manage plant parasitic nematodes (Gill \& Lewis, 1971 and Nisbet et al., 1993).

In certain reports, the nematicidal mechanisms of neem were suggested the involvement of phenolic compounds absorbed systemically by the roots might have induced tolerance against nematodes (Mohan, 2011). The decomposition of neem formulation in soil release ammonia, formaldehyde, phenols and fatty acids which is very toxic to plant parasitic

Egypt. J. Hort. Vol. 45, No. 2 (2018) nematodes (Khan et al., 1974). Furthermore, the direct toxicity of neem formulations is due to the active constituents such as nimbin, salanine, thionemone, azadirechtin and nimbidine (Khan et al., 1974 and Devakumar et al., 1985). Moreover, it was suggested that the efficacy of neem constitutes on plant parasitic nematodes could be refer to chemoreceptors (Amphids and Phasmids), which are responsible for recognizing the host plant and work as repellent compound (Khalil, 2013). Also, the relative low effect of Azadirachtin in our study may be also due to the rapid degradation of neem by the environmental factors such as UV radiation in sunlight, heat, air moisture, acidity and enzymes present in foliar surfaces (Khalil, 2013).

In respect to antagonistic microorganisms such as Bacillus sp. and Trichoderma sp. it was proved to be effective against the plant parasitic nematodes in certain investigations. It was found that Bacillus subtilis succeed to reduce Tylenchulus semipenetrans on mandarin trees. The recorded reduction in soil population of T. semipenetrans was at range from 59.7 up to $74.4 \%$. Meanwhile, the Fruit yield ( $\mathrm{kg} /$ tree) was increased with $B$. subtilis by $31.4 \%$ (Hammam et al., 2016). Meanwhile, El-Mohamedy et al. (2016) reported that some isolates of Trichoderma viride, T. harzianum and Bacillus subtilis were effective against the Tylenchulus semipenetrans on Sour orange seedlings under greenhouse conditions.

Effect of three bio-pesticides and oxamyl on fruit yield of Washington navel orange trees

The obtained results as shown in Table 2 indicated that oxamyl $\left(\right.$ Vydate $\left.^{\circledR}\right)$ treatment, in both seasons, resulted in the highest significant increasing effect on number of fruit/tree, average fruit weight and fruit yield, where the values are $162.25,321.88$ (gm.) and 10.97 ton/ feddan, respectively at the $1^{\text {st }}$ season, while the corresponding values are 201.00, 278.13 (g) and 11.74 ton/feddan at the $2^{\text {nd }}$ season. The remaining treatments had increasing significant influences when comparing with the untreated control trees.

As an overall average of both experimental seasons, the yield as $\mathrm{kg} /$ tree of navel oranges receiving the different nematicides treatments could be arranged in the following descending order: oxamyl, azadirachtin, abamectin, the mixture of T. album $+B$. megaterium, and then the untreated control (Table 2). 

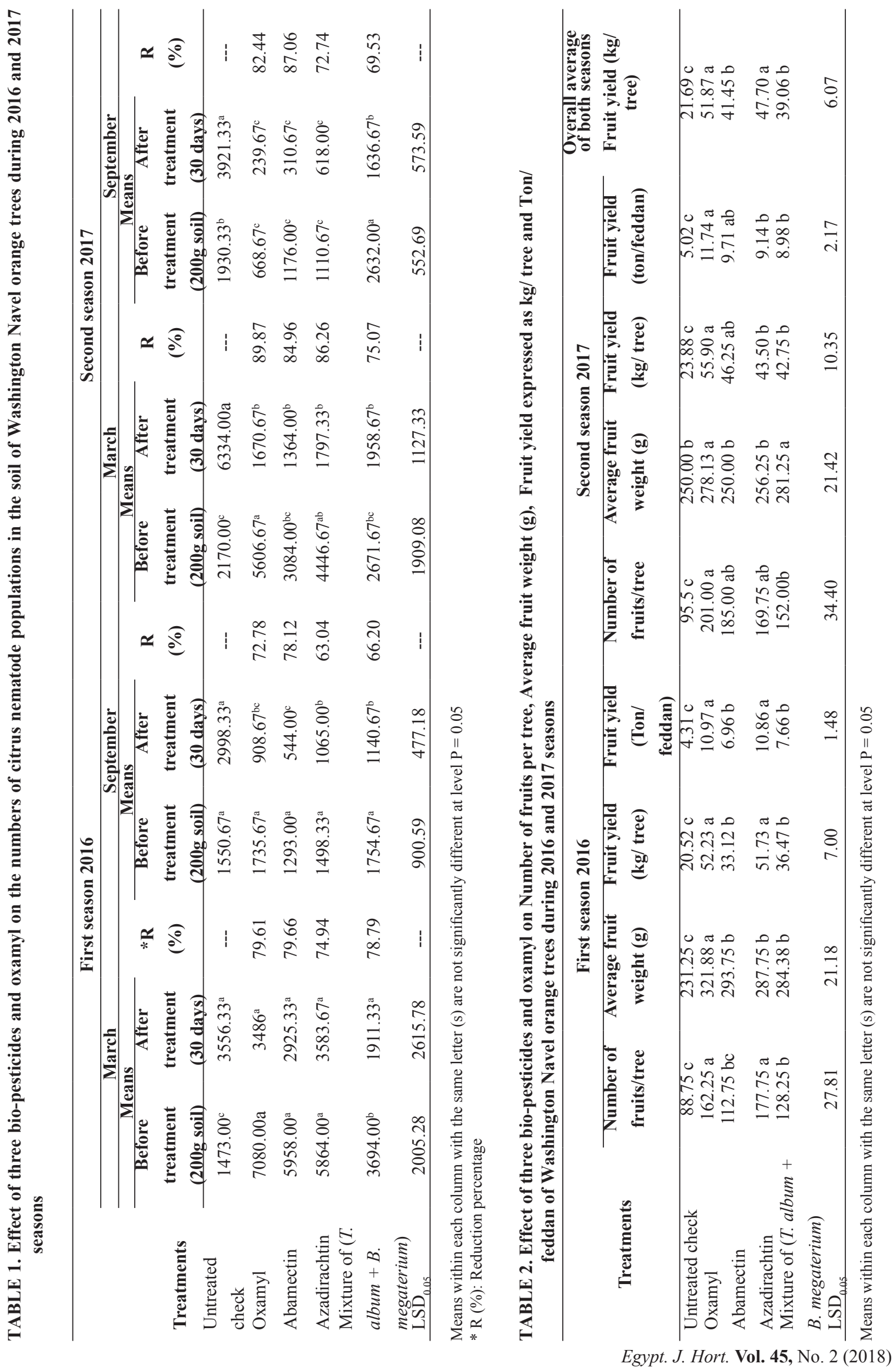
The present results are in harmony with Verdejo-lucas and McKenry (2004) who found that Tylenchulus semipenetrans nematode caused yield losses was in range of 10-30\% depending on the level of infestation. Likewise, Walker and Morey (1999) reported that granular cadusafos nematicide has shown superior efficacy against the citrus nematode and reduced citrus nematode populations. Moreover, Deepa et al. (2011) used Pseudomonas florescens that are commercially available at $20 \mathrm{gm}$./tree it was the most the most effective treatment to reduce $T$. semipenetrans populations of infected lemon trees $(79.49 \%)$ and increased fruit yield three folds compared to untreated control. this bio agent nematicide recorded the highest fruit weight over control.

In Egypt, El-Nagdi et al. (2010) found that the best nematicide control was achieved with the highest rate of Agerin ${ }^{\circledR}$ (containing an isolate of Bacillus thuringiensis), in balady mandarin orchard. This treatment reduced reproduction rate of the nematode in both seasons. They added that both Agerin ${ }^{\circledR}$ 0.5\% WP of abamectin (containing fermentation products of Streptomyces avermitilis as bio-agents are significantly increased fruit yield expressed as fruit number or weight compared to untreated control. It was concluded that these two bio-agents also have low associated production costs and are considered to be environmentally safe. Noteworthy, Timmer and French (1979) using grapefruit trees (Citrus paradisi) reported that soil application of DBCP (1,2-dibromo-3chloropropane) reduced nematode populations and rust mite damage increased yield and fruit size. Otherwise, Duncan (1989) as well as Davis and Wilhite (1985) observed that both fenamiphos and oxamyl weren't showed any impacts on either fruit yield or size of both grapefruit and some citrus trees.

The correlation analysis between the number of nematode populations due to the infestation of soil samples collected after 30 days from the bio-pesticides and oxamyl application in either March or September might support such notation. Negative and significant correlation coefficients, especially in the second season were observed between number of soil population and both total fruit number / tree and fruit yield during both seasons of study (Table 3). This relation was negative but insignificant after 30 days from application in either March or September in the first season.

Effect of three bio-pesticides and oxamyl on some Egypt. J. Hort. Vol. 45, No. 2 (2018) physical fruit properties

The effects of three bio-pesticide products and oxamyl were evaluated on physical fruit properties that included (fruit length, diameter, pulp weight, rind and fruit weights, peel thickness and fruit juice volume) are presented in Table (4). In general, the gained data indicated that all treatments during both seasons significantly increased the studied physical parameters of fruit in compared with untreated check. The only exception was noticed in rind weight which didn't significantly affected by the evaluated treatments. The treatment of oxamyl, during both seasons, was significantly superior in all fruit physical properties comparing with all other treatments including untreated check. Conversely, rind thickness property showed that oxamyl treatment had significantly the lowest values during the both seasons of 2016 and 2017 (Table 4).

Results of the present study are in general agreement with those reported by Wheaton et al. (1985) who stated that soil applied with oxamyl increased the average fruit size (length and diameter) and weights of Valencia orange fruit. In addition, El-Nagdi et al. (2010) found that the Bacillus thuringiensis $\left(\right.$ Agerin $^{\circledR}$ ) and abamectin $\left(\right.$ Vertemic ${ }^{\circledR}$ ), markedly improved fruit quality of mandarin trees. Also, they found that these treatments suppressed the population of $T$. semipenetrans and improved nutritional status.

Many investigators, such as Timer and French (1979), Garabedian and Van Gundy (1983), Philis (1995 and 1997) revealed that soil applied with chemical nematicides reduced citrus nematode populations ( $T$. semipenetrans) on citrus and grapefruit trees, as well as significantly increased fruit yield, fruit size, and improved other external fruit properties compared to the untreated control during two seasons. On the contrary, Abdelaal et al. (2010) reported that certain microbial biofertilizers as nematicides didn't significantly had an effect on fruit peel thickness of Washington navel oranges.

The impact of three bio-pesticides and oxamyl on some chemical fruit properties

The efficacy of applied treatments (abamectin, azadirachtin, the microbial mixture and oxamyl) on total soluble solids (TSS \%), acidity (\%) and vitamin $\mathrm{C}(\mathrm{mg} / 100 \mathrm{ml}$ juice $)$ are shown in Table 5. The obtained results revealed that azadirachtin, oxamyl and abamectin during the both seasons had enhanced the TSS (\%) with estimated values of $13.45,13.38$ and $12.90 \%$, respectively, at the 
first season. While, the corresponding values were $14.00,13.98$ and $13.50 \%$ in the second season, respectively. However, abamectin was the only treatment that recorded increasing effect in acidity (1.02 and1.08\%) and vitamin C (44.78 and 47.82 $\mathrm{mg} / 100 \mathrm{ml}$ juice) in first and second seasons, respectively. Meanwhile, the microbial mixture (T. album + B. megaterium) had also increased the vitamin $C$ by 44.37 and $45.44 \mathrm{mg} / 100 \mathrm{ml}$ juice during first and second seasons, consecutively.

On the other hand, azadirachtin treatment markedly reduced the juice acidity percentage during both seasons (2016 and 2017) as shown in Table 5. Our results are similar to previous studies of Wheaton et al. (1985) who reported that average brix percentages (TSS \%) in the fruit juice of both Valencia and Halmin oranges, were increased linearly with the increment of Aldicarb doses. They attributed the increases in juice brix to an added benefit of Aldicarb Treatment. Moreover, El-Ngdi et al. (2010) found that both Bacillus thuringiensis (Agerin $^{\circledR}$ ) and abamectin $\left(\right.$ Vertemic $^{\circledR}$ ), significantly increased $\mathrm{TSS} \%$ and ascorbic acid (V.C) content in the fruit juice of mandarin trees. Meanwhile, Abdelaal et al. (2010) observed that microbial strains of Pseudomonas florescence 843 and Azospirillium brasilense W 24 at the rate of 300 or $500 \mathrm{ml} /$ tree exhibited significant increases in total soluble solid (TSS) and fruit juice acidity (\%), particularly in Washington Navel orange trees during the first season. Moreover, the content of vitamin C in fruit juice was promoted with $P$. florescence significantly. Conversely, it was mentioned that the nematicide aldicarb did not affect juice acidity or ratio of Florida citrus (Wheaton et al., 1985).

Effect of three bio-pesticides and oxamyl against citrus nematode on leaf area and some leaf mineral composition of Washington navel orange trees:

Data concerning the influence of oxamyl, abamectin, azadirachtin and a mixture of T. album + B. megaterium, on the leaf area $\left(\mathrm{cm}^{2}\right)$ shown in Table 6. The different applied treatments had increasing effects on the aforementioned parameter.

TABLE 3. Correlation, regression coefficient for treatment between the numbers of nematode population density in soil samples collected after 30 days from three bio-pesticides and oxamyl application for fruit number per tree and fruit yield (kg/tree) in Washington Navel orange trees during 2016 and 2017 seasons

\begin{tabular}{|c|c|c|c|c|c|}
\hline \multirow{2}{*}{$\begin{array}{l}\text { The number } \\
\text { of nematode } \\
\text { population } \\
\text { densities }\end{array}$} & \multirow[b]{2}{*}{ Relations } & \multicolumn{2}{|c|}{ First season (2016) } & \multicolumn{2}{|c|}{ Second season (2017) } \\
\hline & & $\begin{array}{c}\text { Total fruit } \\
\text { number/ tree }\end{array}$ & $\begin{array}{l}\text { Fruit yield }(\mathrm{kg} / \\
\text { tree) }\end{array}$ & $\begin{array}{c}\text { Total fruit number/ } \\
\text { tree }\end{array}$ & $\begin{array}{l}\text { Fruit yield (kg/ } \\
\text { tree) }\end{array}$ \\
\hline \multirow{3}{*}{$\begin{array}{c}\text { After } 30 \text { days } \\
\text { of application } \\
\text { (March) }\end{array}$} & ${ }^{\#} \mathrm{r}$ & $-0.16 \mathrm{~ns}$ & $-0.15 \mathrm{~ns}$ & $-0.66^{* *}$ & $-0.63^{* *}$ \\
\hline & $\$ b$ & -0.006 & -0.002 & -0.019 & -0.005 \\
\hline & $\begin{array}{c}@ \\
\text { Equation }\end{array}$ & $\hat{y}=153.06-0.006 X$ & $\hat{y}=43.50-0.002 X$ & $\hat{y}=206.12-0.019 X$ & $\hat{y}=56.05-0.005 X$ \\
\hline \multirow{2}{*}{$\begin{array}{c}\text { After } 30 \text { days } \\
\text { of application } \\
\text { (September) }\end{array}$} & $\mathrm{R}$ & $-0.35 \mathrm{~ns}$ & $-0.49 \mathrm{~ns}$ & $-0.70^{* *}$ & $-0.72^{* *}$ \\
\hline & Equation & $\hat{y}=158-0.018 X$ & $\hat{y}=49.43-0.008 X$ & $\hat{y}=197.50-0.027 X$ & $\hat{y}=52.32-0.009 X$ \\
\hline \multirow{2}{*}{ LSR } & 0.05 & 0.44 & 0.44 & 0.44 & 0.44 \\
\hline & 0.01 & 0.56 & 0.56 & 0.56 & 0.56 \\
\hline
\end{tabular}

${ }^{\#} \mathrm{r}=$ Correlation coefficient, ${ }^{\$} \mathrm{~b}=$ Regression coefficient, ${ }^{\circledR} \hat{\mathrm{y}}=\mathrm{a}+\mathrm{b} X$ 


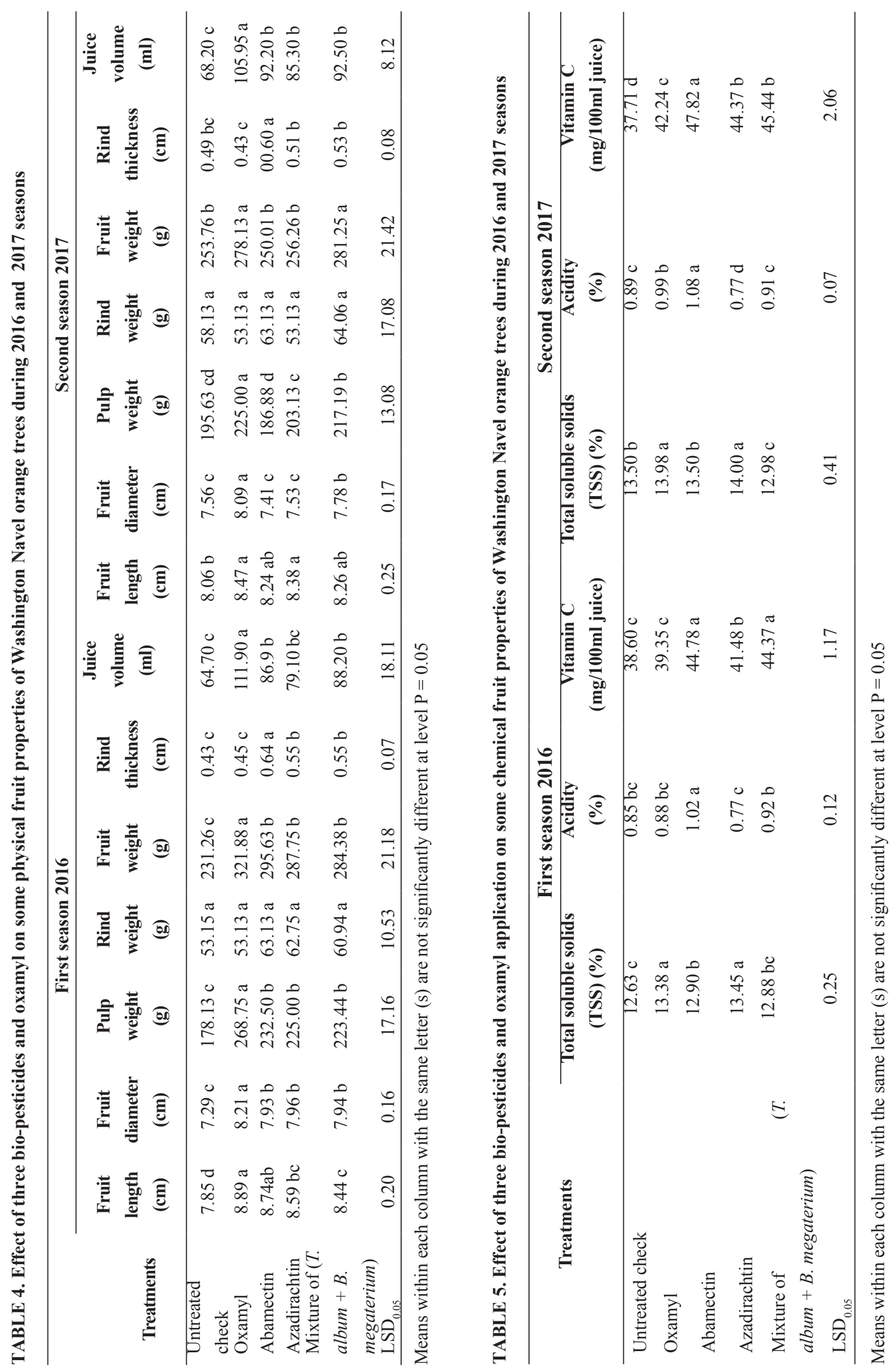

Egypt. J. Hort. Vol. 45, No. 2 (2018) 
The obtained results are in harmony with ElNagdi et al. (2010) who found that both Agerin $^{\circledR}$ and Vertemic ${ }^{\circledR}$ increased the leaf area of mandarin trees relative to untreated check, with increases being positively correlated with the increases in application rate of the formulations. They added that the smallest leaf area of mandarin trees was recorded in untreated trees. They also attributed the increment of the leaf area due to applied these bioproducts to stimulate, especially carbohydrates and proteins, and enhancement of the formation and movement of natural hormones, which are vital to improved cell division, especially in the meristem tissues. This explanation agrees with those reported by Nomier (2000), Hafez (2001) and Mahmoud and Hafez (2004). Similarly, Philis (1997) found that heavily nematode infested trees exhibit symptoms of poor growth, reduced fruit size, twig die-back and small leaves. Nakhla et al (1998) reported that inorganic-n(ammonium nitrate $33.5 \%$ and calcium nitrate $15.5 \%$ ) significantly $(\mathrm{P} \leq 0.05)$ increased fruiting intensity and total sugars content as well as significantly $(\mathrm{P} \leq 0.01)$ decrease populations of the nematode in both seasons. Also, concluded that application of organic-N $75 \%$ plus inorganic-N $25 \%$ was the most effective combination treatments in this respect.

On the other hand, obtained results in Table 6 indicated that the abamectin treatment, in both seasons, gave significantly the highest percentages in both leaf nitrogen and phosphorus content compared with the untreated control trees. The percentages of nitrogen and phosphorus values were $2.69,0.59$ at the first season and 3.32 and 0.60 at the second one, respectively. Similarly, significantly the highest percentages of both leaf calcium and magnesium content were obtained by oxamyl nematicide application compared to the untreated control where the values were 5.37 and 0.87 at the $1^{\text {st }}$ season and 5.32 and 0.92 at the $2^{\text {nd }}$ one, respectively. In general, the control treatment, in both seasons, gave significantly the lowest values in all leaf macro nutrients content studied herein during both years of study (Table 6). Generally, the assessed treatments had a positive effect on leaf minerals of Washington navel orange trees.

Concerning leaf potassium content in both seasons, all evaluated treatments generally increased leaf potassium percentages compared with untreated control (Table 6). Both abamectin and T. album $+B$. megaterium during both seasons recorded the highest leaf potassium content significantly in compared with the rest treatments including the control where the values were 1.60 and $1.56 \%$ at $1^{\text {st }}$ season and 1.54 and $1.66 \%$ at the $2^{\text {nd }}$ one, for abamectin and the mixture of $T$. album $+B$. megaterium, respectively. Nevertheless, oxamyl also markedly exhibited increment in potassium percentage than the untreated treatment. The significantly lowest potassium percentages were obtained from the untreated control trees where the values were 0.75 and $0.85 \%$, in the first and the second seasons, consecutively.

In accordance with these results are those reported by Wheaton et al. (1985) who stated that application of oxamyl to citrus trees grown in presence of citrus nematode increased leaf phosphorus, calcium and magnesium contents, but leaf nitrogen wasn't affected by oxamyl treatment. Noteworthy, it was reported that macro nutrients content of mandarin leaves was significantly increased with applied treatments of $B$. thuringiensis and abamectin (El-Nagdi et al., 2010). Also, they found that the highest content of macro nutrients $(\mathrm{N}$, $\mathrm{Ca}$ and $\mathrm{Mg}$ ) are correlated with the highest applied rates of $B$. thuringiensis and abamectin. Furthermore, the leaf phosphorus and potassium contents showed gradual augmentation with increasing doses of products during both seasons. On the contrary, in the same year, Abdelaal et al. (2010) concluded that both nitrogen and phosphorus percentages were significantly increased due to application of microbial bio-fertilizer (as nematicide) with the two examined strains (Azospirillium brasilense and Pseudomonas florescence) compared by control. They explained that strain of $A$. brasilense gave high nitrogen percent than the strain of $P$. florescence which is a free living nitrogen fixing bacteria. Additionally, the phosphorus and potassium content were also increased due to application of bio-fertilizer with the two examined strains. Atwaia and El-Dosouky (1997) and Abdalla et al. (1998) reported that the improvement in nutrient status followed by the treatment with these two bioproducts $\left(\right.$ Agerin ${ }^{\circledR}$ and Vertemic ${ }^{\circledR}$ ) might be to faster absorption of the nutrient via citrus roots.

The relation between the numbers of soil nematode populations and average of leaf area was statistically examined by calculating the correlation coefficient between these two variables as shown in Table 7. The correlation coefficient between the number of citrus nematode populations and the leaf area in Washington navel Orange trees, in both seasons was negative and insignificant, i.e. with increasing number of nematode population density, average leaf area was reduced. The only exceptional case was after 30 days from the application of 


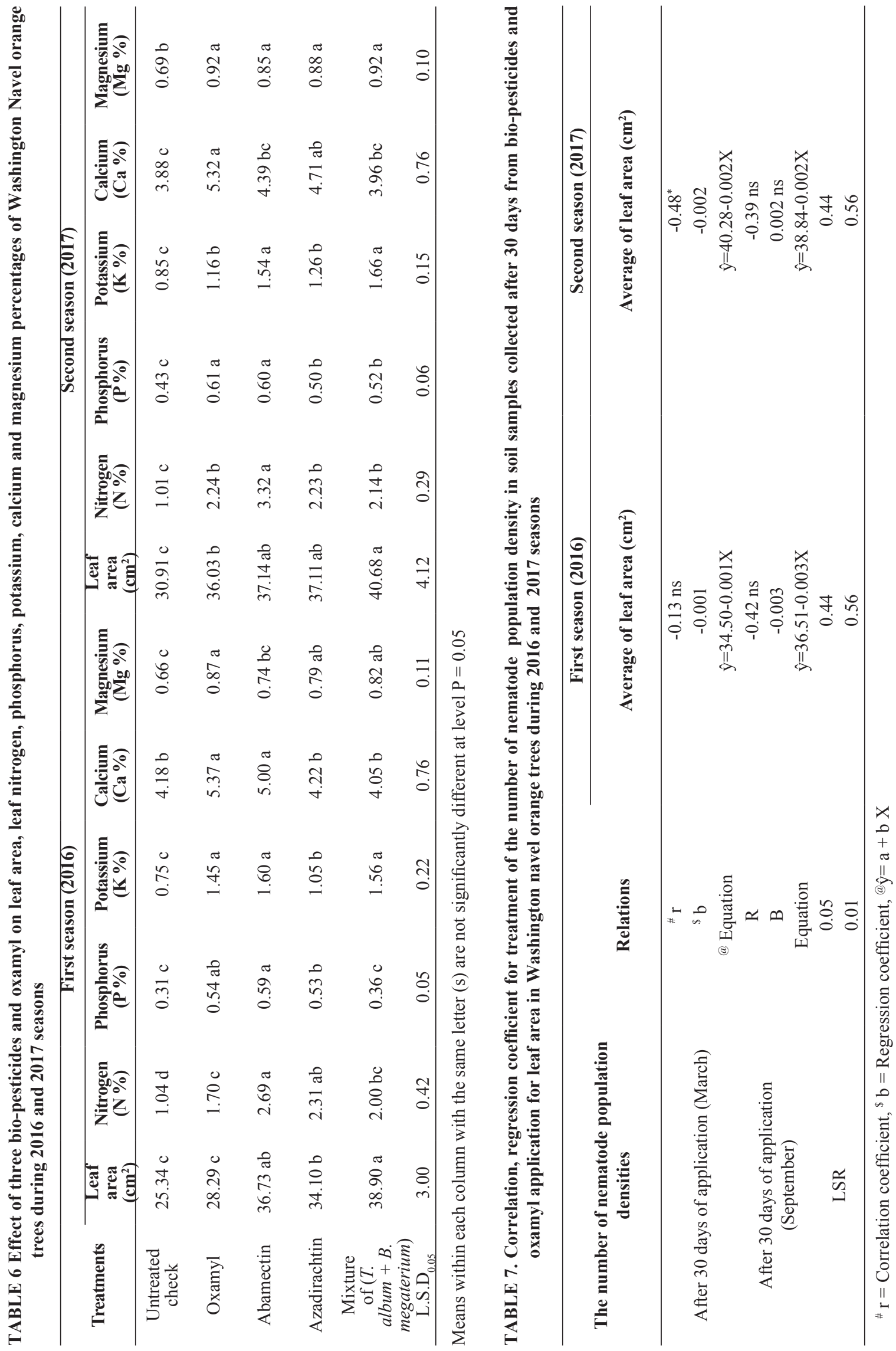

Egypt. J. Hort. Vol. 45, No. 2 (2018) 
products in March during the second season, the correlation coefficient was negative and significant (Table 7)

\section{Conclusion}

Overall, it could be concluded that oxamyl and/or abamectin were the efficient treatments to reduce the citrus nematode population densities in soil and significantly enhanced fruit yield expressed as weights or numbers. Moreover, oxamyl treatment improved all physical fruit properties and fruit juice content of total soluble soils, as well as increased leaf macro nutrient content. While, abamectin increased the juice content of acidity and vitamin C. Nevertheless, the combination between T. album and B. megaterium increased leaf area.

Acknowledgment:

No acknowledgments were declared

Funding statements:

No funding was provided

Conflicts of interest:

No conflicts were declared

\section{$\underline{\text { References }}$}

A.O.A.C (1995) Official methods of Analysis of the association of official Agricultural Chemists published by the A.O.A.C, $14^{\text {th }}$ ed . Washington D.C .

Abdalla, K.M., Abou Sayed, T.A.A. and El-Batal, M.M.H. (1998) Response of Washington Navel orange and Valencia orange trees to some GA3 and Yeast treatments. Egyptian J. Plant Sci., 13, 319334.

Abdelaal, S., El-sheikh, M.H., Hassan, H.S.A. and Kabeil, S.S. (2010) Microbial bio-fertilization approaches to improve yield and quality of Washington Navel orange and reducing the survival of nematode in the soil. J. Amer. Sci., 6(12): 264271.

Ahmed, M.S., Tariq, M. and Riza, A. (2004) Some studies on the control of citrus nematode (Tylenchulus semipenetrans) by leaf extracts of three plants and their effects on plant growth variables. Asian J. Plant Sic., 3, 544-548.

Atwaia, A.A.R. and El-Desoky, S.A. (1997) Trials for improving fruit set, yield and fruit quality of Washington Navel orange by application of some growth regulators and yeast extracts natural source of phytohormons. J. Agric. Sci., Moshtohor, Zagazig Unive., Egypt, 35, 1613-1632.
Ayoub, S.M. (1980) Plant nematology, an agricultural training aid. Secramanto, California, USA, Nema aid Publications, $195 \mathrm{p}$.

Barker, K.R. (1985) Sampling nematode communities. In: An advanced treatise on Meloidogyne, Vol. II, Methodology Barker, K. R., Carter, C. C. and Sasser, J. N. (Ed.), Graphics, North Carolina State University Raleigh, USA, pp. 3-17

Becker, W.F. (1999) The effect of abamectin on garlic infected by Ditylenchus dipsaci. Nematol. Bras., 23, 1-8.

Blackburn, K., Alm, S.R. and Yeh, T.S. (1996) Avermectin B1, isazofos, and fenamiphos for control of Hoplolaimus galeatus and Tylenchorhynchus dubius infesting Poa annua. J. Nematol., 28, 680-687.

Cheng, K.L. and Bray, R.H. (1951) Determination of calcium and magnesium in soil and plant material. Soil Sci., 72, $449-458$.

Costat software. (2005) Microcomputer program analysis, Cohort software, Version 6.303, Monterey, CA, USA.

Davis, R.M. and Wilhite, H.S. (1985) Control of Tylenchulus semipenetrans on citrus with fenamiphos and oxamyl. Plant Dis., 69 (11), 974-976.

Deepa, S.P., Subramanian, S. and Ramakrishnan, S. (2011) Biomanagment of citrus nematode, Tylenchulus semipenetrans cobb on lemon (Citrus limonia L.). J. Biopest., 4 (2), 205-207.

Devakumar, C., Goswami, B.K. and Mukherjee, S.K. (1985) Nematicidal principles from neem (Azadirachta indica) part 1, Screening of neem kernel fraction against Meloidogyne incognita. Indian J. Nematol., 15, 121-124.

Duncan, L.W. and Cohn, E. (1990) Nematode parasites of citrus. pp. 321-346 in M. Luc, R. A. Sikora and J. Bridge, eds. plant parasitic nematodes in subtropical and tropical agriculture. Wallingford, UK, CAB International.

Duncan, L.W. (1989) Effect of fenamiphos placement on Tylenchulus semipenetrans and yield in a Florida citrus orchard. J. Nematol., 21(45), 703-706.

El-Mohamedy, R.S.R., Mostafa, M.A.H., Farid, A. and Mahfouz, M.M.A. (2016) Biological soil treatment to control Fusarium solani and Tylenchulus semipenetrans on sour orange seedlings under greenhouse conditions. International J. Chem. Tech. Res., 9, 73-85.

Egypt. J. Hort. Vol. 45, No. 2 (2018) 
El-Nagdi, W.M.A., Hafez, O.M. and Saleh, M.A. (2015) Impact of a biocide abamectin for controlling of plant parasitic nematodes, productivity and fruit quality of some date palm cultivars. Sci. Agri., 11, 20-25.

El-Nagdi, W.M.A., Yossef, M.M.A. and Hafez, O.M. (2010) Effects of commercial formulations of Bacillus thuringiensis and Streptomyces avermitilis on Tylenchulus semipenetrans and on nutrition status, yield and fruit quality of mandarin. Nematol. Medit., 38, 147-157.

Evenhunis, B. (1976) Nitrogen determination. Dept. Agric. Res., Royal tropical Inst., Amsterdam.

Evenhunis, B. and Dewaard, P.W. (1980) Principles and practice in plant analysis. F.A.O. Soils Bull., 35, 152-163.

Garbedian, S. and Van Gundy, S.D. (1983) Alternative for DBCP for nematode control. Citrograph, 38, 40-46.

Gill, J.S. and Lewis, C.T. (1971) Systemic action of an insect feeding deterrent. Nature, 232: 402-403.

Gomez, K.A. and Gomez, A.A. (1984) Statistical Procedures for Agriculture Research. $2^{\text {nd }}$ ed., John wiley and Sons, New York.

Hafez, O.M. (2001) Effect of some nutrients, paclobutrasol and active dry yeast on growth, flowering, productivity and storage behavior of Anna apple. PhD Thesis, Faculty Agric., Cairo Univ., Cairo, Egypt, 224 p.

Hammam, M.M.A., El-Nagdi, W.M. and Abd-Elgawad M.M.M. (2016) Biological and chemical control of the citrus nematode, Tylenchulus semipenetrans (Cobb, 1913) on mandarin in Egypt. Egyptian J. Biol. Pest Control, 26 (2), 345-349

Hamid, G.A., Van Gundy, S.D. and Lovatt C.J. (1988) Phenologies of the citrus nematode and citrus roots treated with oxamyl. pp. 993-1004, in R. Goren and K. Mendel, eds. proceedings of the $6^{\text {th }}$ international Citrus Congress. Tel-Aviv, Israel: Balaloan Publishers.

Henderson, C.F. and Tilton, E.W. (1955) Tests with acaricides against the brown wheat mite. J. Econ. Entomol., 48, 157- 160.

Huang, W.K., Sun, J.H., Cui, J.K., Wang, G.F., Kong, L.A., Peng, H., Chen, S.L. and Peng, D.L. (2014) Efficacy evaluation of fungus Syncephalastrum racemosum and nematicide avermectin against the root-knot nematode Meloidogyne incognita on cucumber. PLoS one, 9 (2), e89717. doi: 10.1371/ journal.pone.0089717.

Egypt. J. Hort. Vol. 45, No. 2 (2018)
Jansson, R.K. and Rabatin S. (1998) Potential of foliar, dip, and injection applications of avermectins for control of plant-parasitic nematodes. J. Nematol., 30, 65-75.

Khalil, M.S. (2013) Abamectin and Azadirachtin as Eco-friendly Promising Biorational Tools in Integrated Nematodes Management Programs. $J$. Plant Pathol. Microb., 4, 174 doi:10.4172/21577471.1000174.

Khalil, M.S.H., Allam, A.F.G. and Barakat, A.S.T. (2012) Nematicidal activity of some biopesticide agents and microorganisms against root-knot nematode on tomato plants under greenhouse conditions. J. Plant Prot. Res., 52, 47-52.

Khan, A.M., Alam, M.M. and Ahmad R. (1974) Mechanism of the control of plant parasitic nematodes as a result of the application of oil-cakes to the soil. Indian J. Nematol., 4, 93-96.

Le Roux, H.F., Pretorius, M.C. and Huisman, L. (2000) Citrus nematode IPM in South Africa. Proceeding of the international Society of Citriculture, 2, 823827.

Lopez-Perez, J.A., Edwards, S. and Ploeg, A. (2011) Control of root-knot nematodes on tomato in stone wool substrate with biological nematicides. $J$. Nematol., 43, 110-117.

Mohamed, K.A.H. and Hafez, O. M. (2004) Effect of foliar spray of some yeast mutants on Valancia orange trees (Citrus sinesis). J. Agric. Sci., 29, 1995-2012.

Mohan, K. (2011) Comparison of inorganic and organic nematicides on the population of soil nematodes in hybrid of Saccharum species. J. Biopest., 4, 201204.

Mordue, A.J. and Nisbet, A.J. (2000) Azadirachtin from the Neem Tree Azadirachta indica: its action against insects. Ann. Soc. Entomol. Brasil, 29, 615 632.

Murphy, J. and Rily, J.P. (1962) A modified single solution method for the determination of phosphorus in natural water. Anal. Chim. Acta., 27, 13-36.

Nakhal, F.G., Ismail, A.E. and Aboul-Eid, H.S. (1998) Effect of some organic and inorganic nitrogen fertilizers on growth and productivity of Balady orange trees in relation to infection of citrus nematode, Tylenchulus semipenetrans. Pak. J. Nematol., 16 (2), 111-126. 
Nisbet, A.J., Woodford, J.A.T., Strang, R.H.C., Connoly, J.D. (1993) Systemic antifeedant effects of azadirachtin on the peach-potato aphid Myzus persicae. Entomol. Exp. Appl., 68, 87-98.

Nomier, S.A. (2000) Effect of some GA3, vitamins and active dry yeast treatments on vegetative growth, yield and fruit quality of Thompson seedless grapevine. Zagazig J. Agric. Res., 27, 1267-1286.

Nordmeyer, D. and Dickson, D.W. (1989) Effect of carbamate,organophosphate and avermectin on oxygen consumption by three Meloidogyne spp. J. Nematol, 21, 472- 476.

Philis, J. (1995) An up-dated list of plant parasitic nematodes from Cyprus and their economic importance. Nematol. Medit., 23, 307-314.

Philis, J. (1997) Effect of citrus nematode control on the yield and fruit quality of grape fruit in Cyprus. Misceffaneaus Report, 66, 3-6.

Saad, A.S.A., Radwan, M.A., Mesbah, H.A., Ibrahim, H.S. and Khalil, M.S. (2017) Evaluation of some non-fumigant nematicides and the biocide avermactin for managing Meloidogyne incognita in tomatoes. Pak. J. Nematol., 35 (1), 85-92
Sorribas, F.J., Verdejo-Lucas, S., Forner, J.B., Alcaide, A., Pons, J. and Ornat, C. (2000) Seasonality of Tylenchulus semipenetrans Cobb and Pasteuria sp. in citrus orchards in Spain. J. Nematol., 32, 622632 .

Steel, R.G.D. and Torrie, J.H. (1980) Principles and Procedures of Statistics: Abiometrical approach. Mc Graw-Hill Book Co. New York.

Timmer, L.W. and French, J.V. (1979) Control of Tylenchulus semipenetrans on citrus with aldicarb, oxamyl and DBCP. J. Nematol., 11 (4), 387-394.

Verrdejo-Lucas, S. and MCKenry, M.V. (2004) Management of the citrus nematode, Tylenchulus semipenetrans. J. Nematol., 36 (4), 424-432.

Walker, G.E. and Morey, B.G. (1999) Effect of chemicals and microbial antagonist on nematodes and fungal pathogens of citrus roots. Australian J. Exp. Agric., 39, 629-637.

Wheaton, T.A., Childers, C.C., Timmer, L.W., Duncan, L.W. and Nikdel, S. (1985) Effect of aldicarb on yield, fruit quality and tree condition of Florida citrus. Pro. Flo. State Hort. Soc., 98, 6-10.

(Received 28/03/2018, accepted $07 / 06 / 2018$

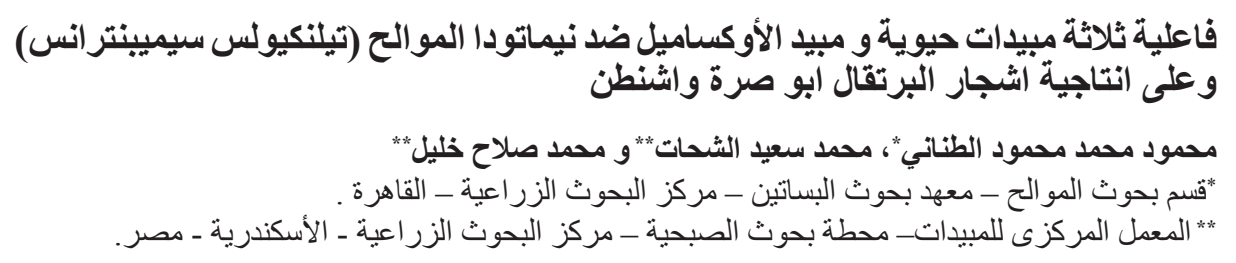

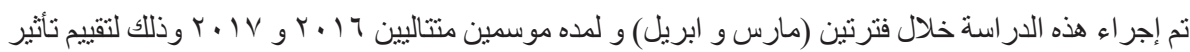

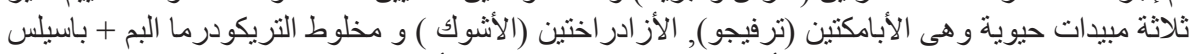

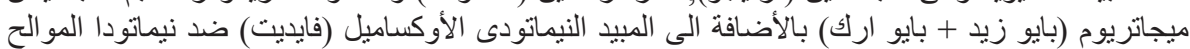

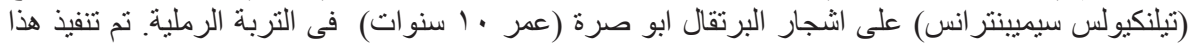

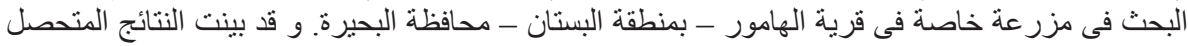

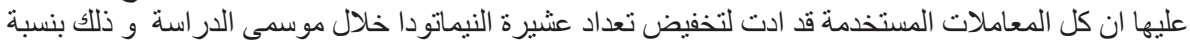

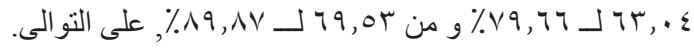

و فى نفس الوقت فإن محصول الثمار قد ازداد معنويا خلال كلا الموسمين مع كل المعاملات المستخدمة

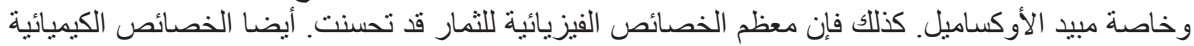

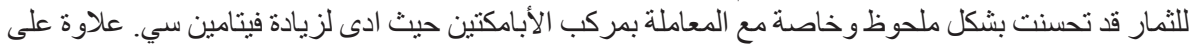

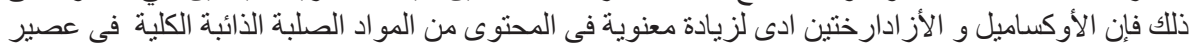
الثمار.

و من ناحية اخري فإن المساحة الورقية قد ازدادت مع كل المعاملات المستخدمة خلال كلا الموسمين. ايضا

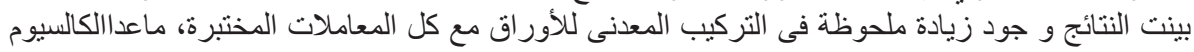

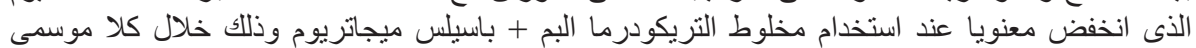
الأر اسة.

Egypt. J. Hort. Vol. 45, No. 2 (2018) 